\begin{tabular}{|c|c|}
\hline Journal STAND: Sports and Development & http://jurnal.unipasby.ac.id/index.php/stand/about/submissions \\
unipa Sunabaya & jurnal.stand@unipasby.ac.id
\end{tabular}

\title{
ANALISIS GERAK TEKNIK DASAR DALAM MELAKUKAN PUKULAN SERVIS PADA ATLET TENIS LAPANGAN USIA 13-15 TAHUN DI SEMEN INDONESIA TENIS AKADEMI
}

\author{
Gatot Margisal Utomo ${ }^{1}$, Daru Cahyono ${ }^{2}$ \\ Pendidikan Jasmani, Universitas PGRI Adi Buana Surabaya \\ gatotmargisalutomo@lppi.unipasby.ac.id ${ }^{1}$
}

\begin{tabular}{l}
\hline Artikel Info \\
\hline Koresponden penulis: \\
Gatot Margisal Utomo \\
\\
$\square$ Diterima 27 April 2020 \\
$\square$ Direview 12 Mei 2020 \\
$\square$ Disetujui 13 Mei 2020 \\
$\square$ Dipublikasi 27 Mei 2020
\end{tabular}

Kata Kunci:

Power tungkai, Kekuatan Otot Lengan, Underbasket Shoot

Keywords:

Leg Power, Arm Muscle Strength,

Underbasket Shoot

\begin{abstract}
Abstrak
Servis merupakan salah satu teknik dasar dalam permainan tenis lapangan, dan merupakan tanda bahwa permainan dimulai. Untuk dapat melakukan teknik serve, diperlukan komponen biomotor yang baik. Adapun komponen biomotor yang diperlukan dalam pertandingan tenis lapangan adalah ketahanan, kekuatan, kecepatan, dan koordinasi. Tujuan penelitian ini adalah untuk mengetahui analisis gerak teknik dasar pukulan servis pada atlet tenis lapangan usia 13-15 tahun di semen Indonesia tenis akademi. Populasi dalam penelitian ini adalah atlet tenis semen Indonesia tenis akademi usia 13-15 tahun yang berjumlah 20 atlet. sampel yang digunakan yaitu 10 atlet semen Indonesia tenis akademi usia 13-15 tahun dengan menggunakan teknik random sampling (acak). Penelitian ini merupakan penelitian eksperimen dengan desain yang digunakan dalam penelitian ini adalah one grup pretest dan pos tes design. Pengambilan data dalam penelitian ini menggunakan test. Teknik analisis data menggunakan analis uji T-Test. Hasil dianalisis menggunakan bantuan SPSS 21.0. ditemukan hasil uji t untuk nilai siq (2-tailled) $0.001<0.05$. Hal ini berarti hasil dari analisis gerak teknik servis tenis lapangan usia 13-15 tahun dikatakan cukup baik. Dengan demikian hipotesis yang berbunyi Hasil Analisis Gerak Teknik Dasar Serve Tenis Lapangan Pada Atlet usia 13-15 Tahun Cukup Baik diterima.
\end{abstract}

\footnotetext{
Abstract

This study aims to determine the relationship between leg power and arm muscle strength with the accuracy of the underbasket shoot on the men's basketball extracurricular team at AL-Islam Krian High School. The method used in this study is qualitative with data collection techniques using tests and measurements. The population in this study was the men's team at the Krian AL-Islam High School basketball extracurricular totaling 40 students. Samples were taken using a purposive sampling technique, with the following criteria: (1) the extracurricular basketball men's team at the AL-Islam Krian High School. (2) a basketball team that meets the criteria of 20 people. The instrument used was leg power measured using a vertical jump test in centimeters. Arm muscle strength is measured by pull up test using units of kilograms. Underbasket shots use underbasket shoot per minute. Data analysis using correlation regression test. The results of the analysis show (1) there is a relationship between leg power and the accuracy of shoot underbasket in the men's basketball extracurricular team with a value of $\mathrm{r} \times 1 . \mathrm{y}=$ $0.485>\mathrm{r}(0.05)(20)=0.444$ (2) there is a relationship between arm muscle strength with the accuracy of the shoot underbasket on the men's basketball team with r x2.y $=0.510>$ r $(0.05)(20)=0.444$.
} 


\begin{tabular}{|c|c|c|}
\hline Journal STAND: Sports and Development & http://jurnal.unipasby.ac.id/index.php/stand/about/submissions \\
unipa Sumalay & jurnal.stand@unipasby.ac.id
\end{tabular}

\section{A. PENDAHULUAN}

Servis merupakan salah satu teknik dasar dalam permainan tenis lapangan, dan merupakan tanda bahwa permainan dimulai. Menurut Yandika (2018) dalam perkembangan servis tidak lagi dianggap sebagai permulaan permainan, tetapi merupakan bentuk serangan pertama. Untuk dapat melakukan teknik serve, diperlukan komponen biomotor yang baik. Adapun komponen biomotor yang diperlukan dalam pertandingan tenis lapangan adalah ketahanan, kekuatan, kecepatan, dan koordinasi. Pada saat melakukan teknik serve, ada beberapa tahap gerakan yang harus dilakukan yaitu dimulai dari tahap persiapandan ayunan, point of contact, dan gerakan lanjutan (follow-through). Melihat kekomplekan gerakan yang harus dilakukan pada saat melakukan teknik serve, maka diperlukan pengawasan yang khusus sehingga dapat mempermudah dan mempercepat anak latih untuk menguasai teknik serve. Ilmu pengetahuan yang dapat mendukung dalam proses pembentukan teknik antara lain analisis gerak melalui pendekatan biomekanika. Dengan demikian hal-hal yang perlu dilakukan adalah: (a) Menganalisis gerak teknik serve, kemudian hasil analisis yang tepat dimanfaatkan sebagai sumbangan dalam pembinaan prestasi khususnya efisiensi gerak, (b) Menghasilkan hal-hal yang dapat menghambat efisiensi gerak teknik servis tenis lapangan. Untuk itu para pelatih tenis lapangan diharapkan mampu melakukan analisis gerak teknik dari sudut pandang biomekanika, sehingga dapat memberikan informasi teknik yang benar dan melakukan terapi terhadap gerak teknik yang belum benar secara tepat kepada anak latih. Saat ini belum banyak pelatih yang melakukan analisis dengan teknik tersebut, dikarenakan keterbatasan alat yang mendukung untuk menganalisis, seperti: aplikasi biomekanika dan alat perekam gerak, jika berbicara tentang atlet usia muda, antara 13-15 tahun, masih belum menguasai teknik pukulan servis dengan baik dan sering kali mereka melakukan double fault untuk pukulan servisnya. Hal ini sesuai dengan pengamatan peneliti selama menjadi pelatih tenis.

Berdasarkan uraian-uraian di atas maka perlu dilakukan analisis mengenai teknik servis tenis lapangan. Dari hasil analisis diharapkan bermanfaat sebagi bahan pertimbangan dalam penyusunan program latihan dan metode melatih teknik yang tepat. Dalam penelitian ini akan meneliti tentang teknik servis tenis lapangan, meliputi: tahap persiapan, tahap takeback, tahap loading, perkenaan bola pada raket dan gerakan ikutan. Oleh karena itu, peneliti mengambil judul "Analisis Gerak Teknik Dasar Melakukan Servis pada Atlet Tenis Lapangan usia 13-15 tahun di Semen Indonesia Tenis Akademi”.

\section{B. METODE PENELITIAN}

Penelitian ini adalah penelitian kualitatif. Dimana dalam penelitian ini peneliti akan melakukan penelitian dengan menggunakan rekaman video kemudia dianalisis per gerakan sesuai dengan proses pembelajaran teknik gerak dasar serve. 


\begin{tabular}{|c|c|}
\hline Unipa Sumabaya & $\begin{array}{c}\text { Journal STAND: Sports and Development } \\
\text { http://jurnal.unipasby.ac.id/index.php/stand/about/submissions } \\
\text { jurnal.stand@unipasby.ac.id }\end{array}$ \\
\hline
\end{tabular}

Dalam pelaksanaan penelitian ini tidak terlepas dari obyek dan subyek penelitian yang diteliti, sehingga yang diteliti adalah yang memiliki kualitas dan ciri yang ditetapkan baik berupa manusia maupun benda. Menurut Sugiyono, (2013: 117) populasi adalah adalah wilayah generalisasi yang terdiri atas obyek dan subyek yang mempunyai kualitas dan karakteristik tertentu yang ditetepkan oleh peneliti untuk dipelajari dan kemudian ditarik kesimpulan. Populasi dalam penelitian ini adalah atlet tenis semen Indonesia tenis akademi usia 13-15 tahun yang berjumlah 20 atlet, Sampel adalah bagian dari populasi, sampel merupakan suatu prosedur dalam menyatakan sebagian dari populasi saja yang diambil dan dipergunakan untuk menentukan sifat dan ciri yang dikehendaki dari populasi. Menurut Sugiyono, (2013: 118) sampel adalah bagian dari jumlah karakteristik yang dimiliki oleh populasi tersebut. Berhubung jumlah populasi dalam penelitian ini sejumlah 20 atlet semen Indonesia tenis akademi usia 13-15 tahun, maka dalam penelitian ini sampel yang digunakan yaitu 10 atlet semen Indonesia tenis akademi usia 13-15 tahun dengan menggunakan teknik random sampling (acak).

Menurut Sugiyono, (2103: 224) teknik pengumpulan data merupakan langkah awal yang paling strategis dalam penelitian, karena tujuan utama dari penelitian ini adalah untuk mendapatkan data. Untuk pengumpulan data pada penelitian Instrumen penelitian yang digunakan dalam penelitian ini adalah dengan menggunakan video dan analisis berdasarkan teori gerak dasar teknik servis. Berikut data angket yang diberikan pada sampel:

\begin{tabular}{|c|c|}
\hline Nilai & Kriteria \\
\hline 5 & $\begin{array}{l}\text { - Posisi pemain berdiri di } \\
\text { belakang garis baseline dan } \\
\text { pegangan benar (hand grip) } \\
\text { Lambungkan bola ke atas } \\
\text { dengan posisi tangan yang } \\
\text { melempar bola lurus keatas } \\
\text { sehingga melambungnya bola } \\
\text { juga lurus } \\
\text { - Pindahkan berat badan ke kaki } \\
\text { yang berada di belakang } \\
\text { kemudian posisi raket seperti } \\
\text { ketika akan diputar, dan lutut } \\
\text { agar sedikit dibengkokkan. } \\
\text { Ketika bola sudah berada di } \\
\text { titik kontaknya dan siap untuk } \\
\text { dipukul, ayunkan raket ke } \\
\text { depan atau pukul bola dengan } \\
\text { raket dan posisi tumpuan berat } \\
\text { badan dipindahkan, dari kaki } \\
\text { belakang ke kaki depan. } \\
\text { Gerakan tangan dan ayunan } \\
\text { lengan mengikuti gerakan } \\
\text { pukulan (followthrough) dan } \\
\text { bersiap kembali pada posisi } \\
\text { awal untuk melakukan pukulan } \\
\text { selanjutnya }\end{array}$ \\
\hline 4 & $\begin{array}{l}\text { Apabila salah satu kriteria tidak } \\
\text { ada }\end{array}$ \\
\hline 3 & Apabila dua kriteria tidak ada \\
\hline 2 & Apabila tiga kriteria tidak ada \\
\hline 1 & Apabila hanya sat kriteria yang ada \\
\hline
\end{tabular}




\begin{tabular}{|c|c|}
\hline uournal STAND: Sports and Development \\
unipa Sumalaya
\end{tabular}$\quad \begin{gathered}\text { http://jurnal.unipasby.ac.id/index.php/stand/about/submissions } \\
\text { jurnal.stand@unipasby.ac.id }\end{gathered}$

\section{HASIL PENELITIAN DAN PEMBAHASAN}

Analisis yang digunakan dalam penelitian ini sebagai bentuk pengujian hipotesis yaitu dengan menggunakan Paired sampel T test (Uji Beda). Sebelum dilakukan Uji beda Paired sampel $\mathrm{T}$ test, dilakukan uji persyaratan data meliputi uji normalitas data, uji homogenitas, dan uji T.

Descriptive Statistics

\begin{tabular}{lccccc}
\hline & & & & \multicolumn{2}{c}{$\begin{array}{c}\text { Std. } \\
\text { Devia } \\
\text { tion }\end{array}$} \\
\hline PreTest & 10 & 21.08 & 24.27 & 22.5170 & 1.1862 \\
PostTest & 10 & 18.28 & 21.32 & 20.8720 & 1.0448 \\
\hline
\end{tabular}

Dari data diatas dapat dijelaskan bahwa, nilai pada jumlah sampel kelompok eksperimen 10. Nilai mean pada kelompok test 1 sebesar 22.5170, test 2 sebesar 20.8720, sedangkan Std. deviation pada kelompok tes 1 sebesar 1.1862, test 2 sebesar 1.0448 .

\begin{tabular}{llrrr}
\multicolumn{5}{c}{ Tests of Normality } \\
\hline Servis & Statistic & Df & \multicolumn{1}{c}{ Sig. } \\
& Pretest & .192 & 20 & $.200^{*}$ \\
& Posttest & .184 & 20 & $.200^{*}$ \\
\hline
\end{tabular}

Dari data diatas dapat dijelaskan bahwa , nilai pada jumlah sampel kelompok eksperimen 10. Nilai sig pada tes 1 sebesar 652 , tes 2 sebesar 699. Nilai angka probabilitas atau signifikan menunjukan $>0.05$ maka distribusi data adalah normal.
Test of Homogeneity of Variance

\begin{tabular}{llcccc}
\hline & & \multicolumn{2}{c}{$\begin{array}{c}\text { Leve } \\
\text { ne }\end{array}$} & & \\
Statis & df & & \\
tic & $\mathbf{1}$ & df2 & Sig. \\
\hline Servis & $\begin{array}{l}\text { Based on } \\
\text { Mean }\end{array}$ & .526 & 1 & 18 & .283 \\
& & & & \\
\hline
\end{tabular}

Berdasarkan data tersebut diketahui bahwa nilai levene statistic yaitu sebesar 526, dan nilai sig sebesar $283>0,05$ maka Ho diterima sehingga dapat disimpulkan bawah data tersebut memiliki varians yang sama atau dengan kata lain homogen.

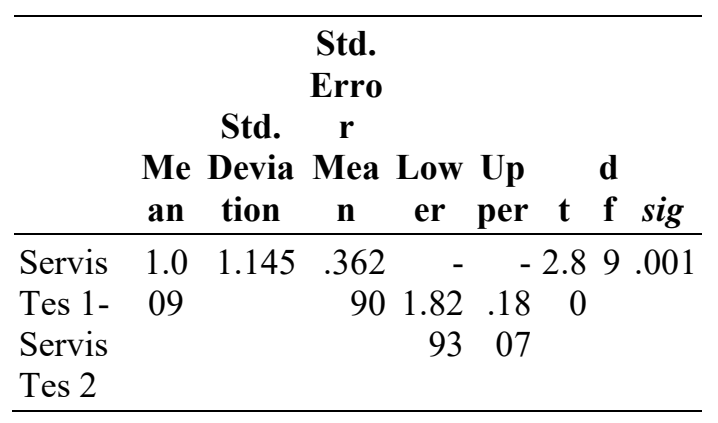

Berdasarkan data diatas diketahui bahwa nilai sig. (2-tailed) pada kelompok eksperimen yaitu sebesar 0.001, sehingga nilai sig. (2-tailed) $<0.05$, maka dapat dinyatakan bahwa Ho ditolak dan Ha diterima. Hal ini berarti hasil dari analisis gerak teknik servis tenis lapangan usia 13-15 tahun dikatakan cukup baik.

Berdasarkan dari hasil penelitian dan pengolahan data yang sudah dilakukan di atas dapat disimpulkan sebagai berikut:

ditemukan hasil uji t untuk nilai siq (2-tailled) $0.001<0.05$. Hal ini berarti hasil dari analisis 


\begin{tabular}{|c|c|}
\hline unipa Sumalaya & $\begin{array}{c}\text { Journal STAND: Sports and Development } \\
\text { http://jurnal.unipasby.ac.id/index.php/stand/about/submissions } \\
\text { jurnal.stand@unipasby.ac.id }\end{array}$ \\
\hline
\end{tabular}

gerak teknik servis tenis lapangan usia 13-15

tahun dikatakan cukup baik.

Dengan demikian hipotesis yang

berbunyi Hasil Analisis Gerak Teknik Dasar

Serve Tenis Lapangan Pada Atlet usia 13-15

Tahun Cukup Baik diterima.

\section{DAFTAR PUSTAKA}

Alim, Abdul. 2014. Analisis Gerak Teknik Servis Tenis Lapangan. Universitas Negeri Yogyakarta.

Bompa, Tudor O (2009). Theory and Methodology of Training. The Key to Athletic Performance, $3^{\text {rd }}$ Edition. Dubuque. Lowa: Kendal/Hunt Publishing Company.

Bornemann, et.al. (2000). Tennis course volume 2. Lesson and Training, English language edition. Hongkong: Barron's Educational Series, Inc.

Bruce E, Marchar R and Miquel C. (2003). Biomechanics of advance tennis. Spain: The international Tennis Federation, ITF.

Greg Emery, (6 November 2001), Biomechanical Analysis of the Tennis Serve, Diambil pada tanggal 23 Agustus 2019

Sugiyono. (2013). Metode Penelitian Kombinasi (Mixed Methods). Alfabeta CV. Bandung.

Yandika FR. (2018). Analisis Gerak Teknik Servis Tenis Lapangan Menggunakan Pendekatan Biomekanika Olahraga. Jurnal Ilmiah Adiraga, 4 (2), 1-5. 